\title{
Foreign Experience of CEOs and Managerial Risk Taking
}

\author{
Siew-Boey, Yeoh ${ }^{\mathrm{a}}$ \\ Chee-Wooi, Hooy \\ Universiti Sains Malaysia
}

\begin{abstract}
Our paper uses a multidimensional analysis to provide a better insight on the relationship between CEO foreign experience and corporate risk-taking. By decomposing the foreign experience of CEOs from developing economies such as Malaysia, we find that CEOs who have studied in OECD countries undertake higher levels of risk-taking and CEOs' foreign working experience may have an adverse effect on risk-taking behaviour especially if the working experience is obtained from non-OECD countries. Additional analysis reveals that younger CEOs and family CEOs with foreign working experience matter in reinforcing the firms' risk-taking activities. Overall, our findings provide implication for researchers and policymakers seeking to nurture risk-taking behaviours and innovativeness in emerging countries.
\end{abstract}

Keywords: CEOs foreign experience, risk-taking, spillover effect, OECD countries JEL classification: G31, G32

\section{Introduction}

A wealth of research indicates inconclusive predictions with respect to the relationship between CEO foreign experience and corporate risk-taking. One strand of literature predicts that CEOs with foreign experience display higher levels of risk propensity as managers with foreign experience are deemed to have greater failure-tolerance levels, better global view and ability to accurately estimate risk and return on investment (Herrmann \& Datta, 2006; Yuan \& Wen, 2018). Another strand of study contends that CEOs with foreign experience may become unfamiliar with local culture after years of life overseas and this results in a detrimental effect to an individual's social network in the firm of the home country, thus leading to a more risk averse behaviour (Georgakakis et al., 2016; Nielsen \& Nielsen, 2013; Yuan \& Wen, 2018).

We contend that these inconclusive results may be attributed to variation in capturing the foreign experience aspect. Prior studies are prone to capture foreign experience using working and/or studying outside the country of origin (Giannetti et al., 2015; Herrmann \& Datta, 2005; Sambharya, 1996; Yuan \& Wen, 2018). Some prior

a School of Management, Universiti Sains Malaysia, 11800 Penang, Malaysia. Email: yeohsb@usm.my; sieweany@gmail.com

b School of Management, Universiti Sains Malaysia, 11800 Penang, Malaysia. Email: cwhooy@usm.my (Corresponding author)

* Acknowledgement to Ministry of Higher Education Malaysia for Research University (Individual) Grant with Project Code: 1001/PMGT/8016091. 
studies only cover international working orientation (Nielsen, 2010) and some studies employ number of years on foreign working assignments experience (Carpenter et al., 2001). As the international experience of CEOs is a multi-dimensional phenomenon, a more comprehensive measure is required to analyse his/her foreign experience. We propose to decompose foreign experience by distinguishing CEOs' studying and working experience, and further analyse the country of origin with respect to whether the foreign studying and working experience are obtained from OECD or non-OECD countries.

In order to decompose the foreign experience, we need a country with a distinct type of foreign experience, that is, a country which has a high rate of students' crossing borders and studying abroad, especially from emerging countries to investigate the effect of spillover from developed countries. Based on the data from UNESCO Institute for Statistics (UIS) on global flow of tertiary-level students, the outbound mobility ratio for emerging markets in East Asia is generally low except for Malaysia. The outbound mobility ratio which captures the rate of students' crossing borders and studying abroad are tabulated in Table 1. As shown in Table 1, Malaysian are highly internationally mobile with a ratio of 4.8 , which is the highest among the emerging markets in East Asia. This is considerably counting on the continuous effort of the Malaysian government in liberalising higher education policy (Yusoff et al., 2000). Besides, Malaysia has gradually liberalised trade and integrated with the world economy in the 1970s. Globalisation in the 1980s and 1990s has promoted international trade expansion and open channels for locals to work overseas. It is also during the early 1990s that Malaysia began to make higher education accessible to the public by providing opportunities for distance learning and studying abroad through collaboration with overseas universities (Yusoff et al., 2000).

Table 1. Outbound mobility ratio of emerging markets in East Asia

\begin{tabular}{lc}
\hline Country & Ratio \\
\hline Cambodia & 2.9 \\
China & 2.2 \\
Indonesia & 0.6 \\
Korea & 3.3 \\
Malaysia & 4.8 \\
Myanmar & 1.1 \\
Philippine & 0.5 \\
Singapore & - \\
Thailand & 1.3 \\
Vietnam & 3.6 \\
\hline
\end{tabular}

Source: UNESCO Institute for Statistics (UIS). http://uis.unesco.org/en/ uis-student-flow

Malaysia thus provides an ideal setting for us to conduct the more refined investigation on foreign experience of CEOs by decomposing them into two categories: CEO with foreign working experience and CEO with foreign education; and to further examine the impact of foreign experience from developed (OECD) countries to the managerial risk-taking of a firm. Being a former British colony, the United Kingdom has 
been the traditional higher education destination for Malaysians due to the historical ties between the two countries. Most Malaysians tend to continue working in foreign countries after completing their studies overseas. A World Bank report shows that Malaysians are working in four key countries, namely Australia, Canada, the United Kingdom and United States, mainly in sectors such as manufacturing, scientific, technical and healthcare services (World Bank, 2015). Prior research shows that after several years of education and/or business experience in developed or OECD countries, returnees has created a significant knowledge transfer and innovation to home countries (Filatotchev et al., 2011).

We use R\&D expenditure and financial leverage as proxies for managerial risktaking as these are the two most widely examined risky investment and financial policies in the previous literature. Although R\&D and leverage are risky corporate policies, they enhance the competitive advantage and economic growth for a firm (Hoskisson et al., 2017). R\&D activities involve long-term multi-stage processes that are full of uncertainty (Holmström, 1989). It is riskier than investments on property, plant and equipment as it involves uncertainty on realisation of expected payoff (Lu \& Wang, 2018). However, when R\&D expenditure leads to improvement of product offerings, it brings a higher level of profitability to the firm (Trajtenberg, 1990). Similarly, financial leverage is a riskier financial choice as debt financing may bring a negative impact on the profitability of a firm (Faccio et al., 2011). However, financial debt is a very flexible fund that can be sourced externally (Norden \& van Kampen, 2013) for the investment of productive assets to support output growth. Besides, it does not reduce the growth for a firm with better investment opportunities (Lang et al., 1996).

Emerging economies generally lack expertise and resources to develop innovative and entrepreneurial activities (Peng, 2001). There is increasing evidence showing that emerging economies in East and Southeast Asia invest far less in R\&D (Carney \& Gedajlovic, 2003). Similarly, Malaysia has hardly increased the R\&D expenditure beyond one percent of the country's gross domestic product (Mahadevan, 2002). Besides, corporate debt in Malaysia has been expanding at a slower pace as compared to other emerging markets. On one hand, firms in Malaysia are averse to exposing themselves to leverage in the aftermath of the Asian financial crisis 1997/98. On the other hand, corporate sectors are facing difficulties to access borrowings due to consolidation of banks and rigid guidelines on financing facilities (Tong \& Ho, 2019). Therefore, we investigate whether the broader views and higher failure tolerance behaviour gained from foreign experience may weaken the risk averse behaviour of CEOs, and promote higher levels of R\&D investment and capital borrowing in the country.

This paper offers several contributions. Broadly, this study contributes to the literature that investigates determinants of CEOs' risk-taking behaviour. Previous research has focused on how characteristics of CEOs such as education level, career tenure and gender affect their risk preference (Barker III \& Mueller, 2002; Bertrand \& Schoar, 2003; Elsaid \& Ursel, 2011). Specifically, this study identifies foreign backgrounds of CEOs as a source of risk preference that influences the risk profile of the firm managed by them. Thus, our research adds to the growing body of literature examining the relationship between CEO foreign experience and risky corporate policy (Yuan \& Wen, 2018). Most of the prior studies examine foreign experience by not 
isolating the working and studying experience (Schmid \& Altfeld, 2018; Yuan \& Wen, 2018). We analyse the foreign experience in depth by decomposing not only the foreign working and studying experience, but also the country of origin from which the CEOs pursue their experience. This allows broadening of our understanding on the effect of CEOs' foreign experience to the managerial risk-taking of the firms.

We also demonstrate that observable managerial personal traits can be used to deduce the strategic choice and performance level of an organisation, as proposed by upper echelons theory. Investors who are able to diversify risk through investment portfolios may prefer firms with riskier policies. Thus, foreign experience of a CEO may serve as one of the criteria for investors in choosing firms as a target of investment. Besides, this study also contributes to literature that investigates the matching between firms and CEOs. We provide evidence that firms may consider the background such as foreign experience of the CEO to match its preferred risk strategies when making hiring decisions. Lastly, our study offers practical implications to policy makers not only in Malaysia, but also other emerging economies. Our study provides insights on the importance of spillover effects from developed countries in transferring knowledge and technical skills to emerging countries. CEOs with foreign experience represent a source of valuable knowledge and foreign experience in developed countries can stimulate innovation and technology advancement. Policy makers of emerging countries may encourage international exposure to promote innovation and entrepreneurial initiatives in the country.

\section{Theory and Hypotheses}

Managerial risk-taking refers to the strategic choice of top managers that are associated with risky consequences arising from uncertainties in the corporate world (Hoskisson et al., 2017). Risk-taking plays an important role in strategic management as it affects the competitive advantage, economic performance and growth of an organisation (Bromiley, 1991). In a corporation, the CEO is the central decision maker that confronts risk-taking decisions on a continual basis (MacCrimmon \& Wehrung, 1990). CEOs tend to face decision challenges due to ambiguous cues and information overload (von den Driesch et al., 2015).

Upper echelons theory suggests that how the executive perceive and interpret the information and situation around them affect their orientation. This orientation is formed by observable experience and psychological properties of executives and are translated into strategic choices such as risk-taking (Hambrick \& Mason, 1984). The theory is grounded on the principle of bounded rationality in which uncertain and informationally complex situations can be predicted (Simon \& March, 1958). Thus, the act of an organisation such as undertaking of risky policies can to a certain extent be explained from the characteristics of the CEO, and CEO foreign experience is one of the observable attributes.

While it is well-established that the act of the firm can be predicted from the foreign background of the CEO, it is unclear how the foreign experience has benefitted the firm. We argue from the resource-based view and failure-tolerance perspective that foreign experience has become a crucial resource in enhancing the competitive 
advantage of a firm. For a resource to create sustainable competitive advantage, it needs to be valuable, rare, non-substitutable and inimitable (Barney, 1991) and CEO's foreign experience possesses all of these attributes (Carpenter et al., 2001). It is rare as executives with international experience remain a relative rarity (Carpenter et al., 2001); it is non-substitutable as these skills cannot be easily obtained through other means (Sullivan, 1994) and be imitated as this experience is a function of unique historical conditions (Daily et al., 2000).

From the perspective of resource-based view, international experience equips CEOs with foreign knowledge and broader view in handling complex management challenges in globalisation of business (Daily et al., 2000). Prior research posits that managers with foreign experience are believed to have a wider global view, better knowledge and greater confidence in estimating risk and return on investment (Herrmann \& Datta, 2006). Talents and specialised skills are formed to resolve difficulties and tolerate uncertainties when managers are working in foreign countries, especially more developed nations (Yuan \& Wen, 2018). From the perspective of failure-tolerance, managers with foreign experience are more tolerant with unsatisfactory results as they have to resolve difficulties when studying or working in foreign countries alone (Yuan \& Wen, 2018). Managers with foreign experience have greater ability in identifying opportunities and making more aggressive decisions. This is because they may have experienced difficulties when they study or work in foreign countries and become more tolerant of risk when confronting unexpected failures (Lumpkin \& Dess, 1996).

However, there are arguments that managers with foreign experience are used to foreign business practices and less receptive to the domestic way of doing things (Nielsen \& Nielsen, 2013). They may become unfamiliar with local culture and how local companies are being operated and managed after years of life overseas. Besides, on one hand, one may become more risk tolerant after experiencing failure; on the other hand, one may become more prudent and less risk tolerant as they learn clearly the possibilities of failure (Yuan \& Wen, 2018). Nevertheless, previous research demonstrated that CEOs with international experience prefer greenfield investments which are of higher risk as foreign direct investment entry mode (Herrmann \& Datta, 2006). Firms with more managers with foreign experience tend to expand business in international markets (Sambharya, 1996). Managers with foreign experience tend to appreciate the importance of R\&D to firm growth and more prone to invest in innovation activities (Yuan \& Wen, 2018).

Hypothesis 1: CEOs with foreign experience are expected to undertake higher levels of risk-taking.

Prior studies argued that international work experience may weaken the ability to handle challenges arising from business environments due to lack of country-specific habitus (Schmid \& Altfeld, 2018). CEOs may be beneficial in the early phase of foreign experience, but over a period of time, added gains from further years of international experience may decrease (Kraimer et al., 2009). Thus, prolonged stays abroad has an adverse effect resulting in diminishing benefits that can be gained from increasing foreign experience (Schmid \& Altfeld, 2018). 
Their management styles and points of views may not be easily accepted by those without foreign working experience. They may become unfamiliar with corporate culture and their operating style and management philosophy may not be accepted by local managers and employees (Yuan \& Wen, 2018). They may also lack the countryspecific set of dispositions, behaviours and expectations that are considered normative by the national corporate elite (Kish-Gephart \& Campbell, 2015; Schmid \& Altfeld, 2018). As successful implementation of risky strategy requires managerial coordination and support from all levels of the organisation, CEOs may become more prudent in their act and risk averse in their strategic choice (Kuratko et al., 2005; Yuan \& Wen, 2018). However, CEOs who merely obtained education from overseas are less susceptible to this problem as they are less likely to be influenced by unfamiliarity of local business culture due to foreign working experience.

Malaysians tend to continue working in foreign countries after studying abroad. Therefore, as compared to CEOs with solely education experience, CEOs with foreign working experience generally spent more years overseas. As a result, CEOs with foreign working experience may undertake lower level or risk-taking due to lacking the countryspecific set of dispositions and facing difficulties in obtaining acceptance and support from all levels of the firm.

Hypothesis 2a: CEOs with foreign working experience are expected to undertake lower levels of risk-taking.

Hypothesis $2 b$ : CEOs with foreign education experience are expected to undertake higher levels of risk-taking.

Prior research shows that returnees from OECD countries play an important role in facilitating international knowledge transfer from developed to emerging countries. They have significant spillover effects that stimulate innovation and technology advancement in emerging economies (Filatotchev et al., 2011). Returning entrepreneurs have gained vital knowledge, entrepreneurial expertise and resources, and can act as a channel of international knowledge transfer from OECD countries to home countries (Saxenian, 2006).

Individuals who have studied or worked in OECD countries have acquired scientific and technical knowledge from the education institution and practical skills from working in the business environment in these developed countries (Dai \& Liu, 2009). Besides, social relationships developed through working abroad in these developed countries facilitate them to have better access to global networks and advanced technology (Filatotchev et al., 2011). Most of these talents who gain their expertise in developed regions such as the US and UK are believed to possess highly specialised skills, creative abilities and are more innovative (Yuan \& Wen, 2018). Innovation is an important mechanism by which firms can draw upon core competencies to create a sustainable competitive advantage (Reed \& DeFillippi, 1990).

Hypothesis 3: CEOs with foreign education and working experience from OECD countries are expected to undertake a higher level of risk-taking relative to CEOs with foreign education and working experience from non-OECD countries. 


\section{Method}

\subsection{Baseline Model}

To test $\mathrm{H} 1$, we set up a baseline model to examine whether CEOs with foreign experience is positively related to managerial risk-taking as given in the model below:

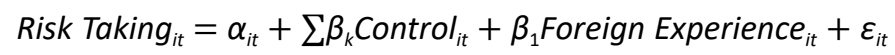

\subsubsection{Dependent Variable}

The dependent variable of this study is managerial risk-taking, which is proxied by research and development (R\&D) and financial leverage (Leverage). R\&D is measured as $R \& D$ expenditure divided by book value of assets. Some studies use R\&D intensity, which has a similar definition as R\&D expenses (Coles et al., 2006; Kini \& Williams, 2012). R\&D expenditure are normally fully expensed. However, as Malaysia adopts the International Financial Reporting Standard (IFRS) that treats R\&D as internallygenerated intangible assets if it meets the definition of assets stated in the International Accounting Standards Board (IASB) framework, we include capitalised R\&D presented under statement of financial position in our analysis of results. Leverage is measured as total long-term debts divided by book value of total assets (Hall, 2012).

\subsubsection{Independent Variable}

Our central explanatory variable is foreign experience of the CEO. It is a dummy variable equals to one if the CEO has foreign experience.

\subsubsection{Control Variables}

Following prior studies (Abdel-Khalik, 2014; Elnahas \& Kim, 2017; Habib \& Hasan, 2017; Lu \& Wang, 2018; Serfling, 2014), we control a series of CEO, firm and board characteristics that have been widely used in previous studies. The control variables include CEO tenure (CEOTenure, the number of years the CEO has been CEO of the firm), CEO age (CEOAge, age of the CEO in the given year, CEO gender (CEOGender, a dummy variable equal one if the CEO is female), firm age (LogFirmAge, the natural logarithm of the number of years since the incorporation of the firm to the year of observation), firm size (LogFirmSize, the natural logarithm of total assets), sales growth (SalesGrowth, measured as annual rate of growth of sales), board size (BoardSize, total number of directors on the board) and board independence (IndBoard, ratio of number of independent directors on the board).

\subsection{Subsequent Analysis on Decomposition of Foreign Experience}

We extend the baseline model by decomposing two distinct types of CEOs foreign experience: CEO with foreign working experience and CEO with foreign education to allow a more refined analysis of the impact of each type of foreign experience. CEO with foreign working experience is a dummy variable equals to one if the CEO has foreign working experience. As most of the Malaysian CEOs has studied abroad and 
stayed back to work in overseas, CEOs with foreign working experience generally has foreign education and working experience. CEO with foreign education is a dummy variable equals to one if the CEO has foreign education. We further examine whether foreign experience from OECD countries facilitates the risk-taking level of the firm. We identify a country as OECD if it is an OECD member by 2017. Table 2 presents the distribution of Malaysian CEOs with foreign experience by OECD countries. We have 502 observations of Malaysian CEOs who have foreign working experience in the OECD countries and 466 observations in the non-OECD countries.

Table 2. Distribution of CEOs' with foreign experience by OECD countries

\begin{tabular}{|c|c|c|c|c|c|c|}
\hline \multirow[t]{2}{*}{ OECD countries } & \multicolumn{3}{|c|}{$\begin{array}{l}\text { CEO with foreign working } \\
\text { experience in OECD countries }\end{array}$} & \multicolumn{3}{|c|}{$\begin{array}{l}\text { CEO with foreign education } \\
\text { experience in OECD countries }\end{array}$} \\
\hline & Frequency & Percent & Cumulative & Frequency & Percent & Cumulative \\
\hline Australia & 114 & 0.23 & 0.23 & 492 & 0.19 & 0.19 \\
\hline Austria & 0 & 0.00 & 0.23 & 0 & 0.00 & 0.19 \\
\hline Canada & 20 & 0.04 & 0.27 & 189 & 0.07 & 0.26 \\
\hline Denmark & 0 & 0.00 & 0.27 & 5 & 0.00 & 0.26 \\
\hline France & 7 & 0.01 & 0.28 & 10 & 0.00 & 0.27 \\
\hline Ireland & 4 & 0.01 & 0.29 & 4 & 0.00 & 0.27 \\
\hline Italy & 0 & 0.00 & 0.29 & 0 & 0.00 & 0.27 \\
\hline Japan & 11 & 0.02 & 0.31 & 32 & 0.01 & 0.28 \\
\hline Netherlands & 0 & 0.00 & 0.31 & 0 & 0.00 & 0.28 \\
\hline New Zealand & 8 & 0.02 & 0.33 & 88 & 0.03 & 0.31 \\
\hline Norway & 0 & 0.00 & 0.33 & 0 & 0.00 & 0.31 \\
\hline Spain & 0 & 0.00 & 0.33 & 0 & 0.00 & 0.31 \\
\hline Sweden & 0 & 0.00 & 0.33 & 0 & 0.00 & 0.31 \\
\hline Switzerland & 0 & 0.00 & 0.33 & 10 & 0.00 & 0.32 \\
\hline UK & 256 & 0.51 & 0.84 & 1085 & 0.42 & 0.73 \\
\hline US & 82 & 0.16 & 1.00 & 694 & 0.27 & 1.00 \\
\hline Total & 502 & 1.00 & & 2609 & 1.00 & \\
\hline
\end{tabular}

As shown in Table 2, the largest number of CEOs obtained their working experience from the UK, followed by Australia and the US. Similarly, the largest number of CEOs also obtained their educational experience from the UK, followed by the US and Australia.

\subsection{Data Collection}

The sample for this study is drawn from public listed companies in Bursa Malaysia that undertake R\&D activities and financial leverage during the period 2009-2017. We do not include finance companies, closed-end funds, exchange traded funds and real estate investment trusts (REITS) as their profitability ratios, growth rates and leverage ratios are calculated differently from non-financial firms. The foreign experience and 
other characteristics of CEOs and board characteristics are hand-collected from the board of directors' profile in the company annual report. Financial data of the firms are gathered from Thomson Reuters Datastream. After removing incomplete data, the final panel of samples consists of 1,827 firm-year observations for R\&D and 6,041 firm-year observations for leverage.

\subsection{Estimation Method}

Prior studies in the area of characteristics of CEOs are affected by endogeneity issues due to its association with upper echelons theory. The theory is built on the notion that executives take action based on information processing of the situation. This may not be so if the action is because of selection bias by which CEOs possessing technology background tend to invest in R\&D expenditure (Hambrick, 2007) and firms which prefer restructuring activities are more likely to select younger CEOs (Li et al., 2017). In order to address this endogeneity problem, we employ the dynamic generalised method of moments (GMM) system estimator (Arellano \& Bover, 1995; Blundell \& Bond, 1998). The dynamic panel data estimations are characterised by individual effects characterising the heterogeneity among the individuals and autocorrelation due to the presence of a lagged-dependent variable among the regressors (Baltagi et al., 2012).

The GMM technique can reduce distortions caused by fixed effect, endogeneity and simultaneity problems. It allows us to treat all independent variables as endogenous (except year and industry dummies) and orthogonally uses their past value as the respective instruments. This estimation technique can produce consistent coefficient estimates but the consistency of the estimator is subject to an optimal choice of instruments and the absence of autocorrelation in error terms. Thus, in order to ensure that GMM results are reliable and consistent, we conduct two diagnostic tests, namely Hansen test of over-identification and Arellano-Bond test for autocorrelation. For Hansen test, the null hypothesis should not be rejected if the instruments used in the GMM estimation are valid. For the Arellano-Bond test, we should expect first-order autocorrelation (AR1) but no second-order autocorrelation (AR2) in the residuals of the first-difference equation if there is no autocorrelation in the error terms.

\section{Analyses and Results}

\subsection{Descriptive Statistics}

Table 3 presents the descriptive statistics of the study. We provide the observation, mean, standard deviation, minimum and maximum value of the variables. The mean value of $R \& D$ expenditure is 0.007 , which exhibits that Malaysian firms averagely only invest $0.7 \%$ of total assets on R\&D activities. The mean value for leverage is 0.087 , indicating that firms in Malaysia averagely undertake $8.7 \%$ of long-term debt as a funding source to finance firms' assets.

We calculate the Pearson correlation matrix of main variables and report the results in Table 4. All the correlation values are between -0.5 and 0.5 , except foreign experience vs CEO with foreign education (0.744). However, this relationship will not affect the results as both of them are not included in the regression models at the 
Table 3. Summary statistics for variable characteristics

\begin{tabular}{lrrrr}
\hline Variables & Mean & S.D. & Min & Max \\
\hline R\&D & 0.007 & 0.019 & 0 & 0.142 \\
Leverage & 0.087 & 0.111 & 0 & 0.591 \\
Foreign experience & 0.614 & 0.487 & 0 & 1 \\
CEO with foreign working experience & 0.157 & 0.364 & 0 & 1 \\
CEO with foreign education & 0.468 & 0.499 & 0 & 1 \\
CEOTenure & 10.566 & 8.535 & 1 & 46 \\
CEOAge & 54.728 & 9.136 & 23 & 96 \\
CEOGender & 0.043 & 0.203 & 0 & 1 \\
FirmAge & 25.604 & 16.211 & 1 & 107 \\
LogFirmSize & 12.957 & 1.451 & 10.253 & 17.726 \\
SalesGrowth & 0.078 & 0.460 & -0.722 & 3.956 \\
BoardSize & 7.921 & 2.145 & 3 & 21 \\
IndBoard & 0.466 & 0.127 & 0.111 & 0.857 \\
\hline
\end{tabular}

Table 4. Pearson correlation of explanatory variables

\begin{tabular}{|c|c|c|c|c|c|c|c|c|c|c|c|c|c|c|}
\hline & & 1 & 2 & 3 & 4 & 5 & 6 & 7 & 8 & 9 & 10 & 11 & 12 & 13 \\
\hline 1 & $R \& D$ & 1 & & & & & & & & & & & & \\
\hline 2 & Leverage & 0.004 & 1 & & & & & & & & & & & \\
\hline 3 & $\begin{array}{l}\text { Foreign } \\
\text { experience }\end{array}$ & $-0.099 *$ & 0.021 & 1 & & & & & & & & & & \\
\hline 4 & $\begin{array}{l}\text { CEO with } \\
\text { foreign } \\
\text { working } \\
\text { experience }\end{array}$ & $-0.074^{*}$ & $0.086^{*}$ & $0.343^{*}$ & 1 & & & & & & & & & \\
\hline 5 & $\begin{array}{l}\text { CEO with } \\
\text { foreign } \\
\text { education }\end{array}$ & $-0.083^{*}$ & $0.101^{*}$ & $0.744^{*}$ & $0.216^{*}$ & 1 & & & & & & & & \\
\hline 6 & CEOTenure & $-0.065^{*}$ & $-0.033^{*}$ & $-0.084^{*}$ & $-0.085^{*}$ & $-0.074^{*}$ & 1 & & & & & & & \\
\hline 7 & CEOAge & $-0.083^{*}$ & -0.006 & $-0.197^{*}$ & $-0.096^{*}$ & $-0.191^{*}$ & $0.446^{*}$ & 1 & & & & & & \\
\hline 8 & CEOGender & -0.014 & 0.000 & $0.052^{*}$ & $0.086^{*}$ & 0.019 & $-0.048^{*}$ & $-0.113^{*}$ & 1 & & & & & \\
\hline 9 & LogFirmAge & $-0.140^{*}$ & $0.043^{*}$ & $0.117^{*}$ & $0.059^{*}$ & $0.057^{*}$ & $0.211^{*}$ & $0.109^{*}$ & 0.013 & 1 & & & & \\
\hline 10 & LogFirmSize & $-0.075^{*}$ & $0.424^{*}$ & $0.154^{*}$ & $0.054^{*}$ & $0.146^{*}$ & $0.059^{*}$ & $0.085^{*}$ & $-0.058^{*}$ & $0.291^{*}$ & 1 & & & \\
\hline 11 & SalesGrowth & $0.063^{*}$ & $0.066^{*}$ & 0.012 & 0.011 & 0.016 & $-0.033^{*}$ & $-0.029 *$ & -0.017 & 0.016 & $0.056^{*}$ & 1 & & \\
\hline 12 & BoardSize & -0.037 & $0.145^{*}$ & 0.017 & -0.008 & 0.018 & $-0.045^{*}$ & $0.059^{*}$ & $-0.063^{*}$ & $0.043^{*}$ & $0.341^{*}$ & 0.012 & 1 & \\
\hline 13 & IndBoard & 0.033 & 0.005 & $0.032^{*}$ & 0.010 & $0.033^{*}$ & $-0.081^{*}$ & $-0.081^{*}$ & 0.023 & $0.115^{*}$ & $-0.056^{*}$ & -0.001 & $-0.252^{*}$ & 1 \\
\hline
\end{tabular}

Note: The table reports correlations of the variables used in multivariate analysis, ${ }^{*}$ denotes significance at $5 \%$ levels (two-tailed). 
same time. Generally the correlation figures among explanatory variables and control variables are relatively low with correlation less than 0.50 , which indicates that there is no problem of multicollinearity.

\subsection{Results}

All continuous variables are winsorised at their $1^{\text {st }}$ and $99^{\text {th }}$ percentiles to reduce the effect of potential bias due to outliers. Models 1 and 2 test $\mathrm{H} 1$ on the relationship between managerial risk-taking and foreign experience. We test $\mathrm{H} 2$ to analyse the two distinct types of foreign experience from Models 3 to 6 . Models 3 and 4 examine CEOs with foreign working experience; and Models 5 and 6 test CEOs with foreign education, with R\&D and leverage respectively. In order to examine H3, we separate the two types of foreign experience into OECD experience and non-OECD experience. Models 7 and 8 examine CEOs with OECD and non-OECD working experience and Models 9 and 10 test CEOs with OECD and non-OECD education. Results of the fulfilment of Arellano-Bond test and the Hansen test are reported. The insignificant figures (at 5\%) of the Arellano-Bond test for $A R(2)$ signify that there is no autocorrelation in the first difference, while the insignificant figures (at 5\%) of Hansen test indicate that the instrumental variables are valid instruments. Both industry and year indicators are included in all regression models.

Table 5 shows the findings of the baseline model. It can be seen that both proxies of managerial risk-taking exhibit negative relationships with the foreign experience of CEOs. Model 1 indicates that foreign experience is negatively associated with R\&D with a coefficient estimate of -0.004 . Similarly, foreign experience is negatively associated with financial leverage with coefficient estimates of -0.006 as shown in Model 2 . This indicates that our results do not support $\mathrm{H} 1$ that CEOs with international experience are more likely to undertake higher levels of risk-taking. Table 6 shows the GMM regression results of $\mathrm{H} 2$. Model 3 and Model 4 show that CEOs with foreign working experience are negatively related with $R \& D(\beta=-0.016)$ and Leverage $(\beta=-0.038)$. As shown in Model 5 and Model 6, CEOs with foreign education have a positive effect on both risktaking activities. CEOs with foreign education show a significant positive coefficient with R\&D $(\beta=0.014)$ and Leverage $(\beta=0.028)$ respectively. Our result supports $H 2$ which predicts a negative relationship between the foreign working experience of CEOs and level of risk-taking.

$\mathrm{H} 3$ relates to the level of risk-taking undertaken by CEOs with foreign experience from OECD countries versus non-OECD countries. As shown in Table 7, Models 7 and 8 show that there is no statistically significant association for CEOs who have worked in OECD countries, but there is a negative relationship between CEOs with working experience in non-OECD countries with coefficient estimates of -0.004 and -0.012 for R\&D and Leverage respectively. Models 9 and 10 show that CEOs with education experience in OECD countries are positively related to R\&D activities with coefficient estimates of 0.004 and leverage with coefficient estimates of 0.025 . There is no significant relationship between CEOs with education experience in non-OECD countries and risk-taking. Thus, our result partly supports H3 which predicts a positive relationship between the foreign experience of CEOs from OECD countries and level of risk-taking. 
Table 5. GMM regression results for testing $\mathrm{H} 1$

\begin{tabular}{|c|c|c|}
\hline & $\begin{array}{c}\text { Model } 1 \\
\text { R\&D }\end{array}$ & $\begin{array}{c}\text { Model } 2 \\
\text { Leverage }\end{array}$ \\
\hline Lagged & $\begin{array}{l}-0.012^{*} \\
(0.095)\end{array}$ & $\begin{array}{l}-0.012 * \\
(0.090)\end{array}$ \\
\hline CEOTenure & $\begin{array}{c}0.000 \\
(0.292)\end{array}$ & $\begin{array}{c}0.000 \\
(0.350)\end{array}$ \\
\hline CEOAge & $\begin{array}{c}0.000 \\
(0.272)\end{array}$ & $\begin{array}{c}0.000 \\
(0.511)\end{array}$ \\
\hline CEOGender & $\begin{array}{c}0.004 \\
(0.390)\end{array}$ & $\begin{array}{c}0.014 \\
(0.204)\end{array}$ \\
\hline LogFirmAge & $\begin{array}{c}0.001 \\
(0.740)\end{array}$ & $\begin{array}{c}0.003 \\
(0.659)\end{array}$ \\
\hline LogFirmSize & $\begin{array}{l}-0.003^{* * *} \\
0.000\end{array}$ & $\begin{array}{l}-0.003 \\
(0.162)\end{array}$ \\
\hline SalesGrowth & $\begin{array}{l}-0.003^{* * *} \\
0.000\end{array}$ & $\begin{array}{c}0.001 \\
(0.719)\end{array}$ \\
\hline BoardSize & $\begin{array}{l}-0.001 * * * \\
(0.001)\end{array}$ & $\begin{array}{c}0.000 \\
(0.504)\end{array}$ \\
\hline IndBoard & $\begin{array}{l}0.012 * * * \\
(0.004)\end{array}$ & $\begin{array}{c}0.018 \\
(0.230)\end{array}$ \\
\hline Foreign experience & $\begin{array}{l}-0.004^{* *} \\
(0.033)\end{array}$ & $\begin{array}{l}-0.006 * * \\
(0.013)\end{array}$ \\
\hline Industry fixed effects & Yes & Yes \\
\hline Year fixed effects & Yes & Yes \\
\hline Number of observations & 1579 & 5225 \\
\hline Number of groups & 225 & 765 \\
\hline$A R(1)$ test & $\begin{array}{l}-2.507^{*} \\
{[0.012]}\end{array}$ & $\begin{array}{l}-5.361^{*} \\
{[0.000]}\end{array}$ \\
\hline$A R(2)$ test & $\begin{array}{l}-0.038 \\
{[0.970]}\end{array}$ & $\begin{array}{l}-0.553 \\
{[0.580]}\end{array}$ \\
\hline Hansen test & $\begin{array}{l}53.957 \\
{[0.590]}\end{array}$ & $\begin{array}{l}71.708 \\
{[0.265]}\end{array}$ \\
\hline
\end{tabular}

Notes: Figures in parentheses are p-values; $* * *, * *$ and $*$ denote significance at $1 \%, 5 \%$ and $10 \%$ respectively. For the $A R(1), A R(2)$ and Hansen tests, figures in [ ] are $p$-values and ${ }^{*}$ denotes significance at $5 \%$.

Table 6. GMM regression results for testing $\mathrm{H} 2$

\begin{tabular}{lllll}
\hline Variables & $\begin{array}{c}\text { Model 3 } \\
\text { R\&D }\end{array}$ & $\begin{array}{c}\text { Model 4 } \\
\text { Leverage }\end{array}$ & $\begin{array}{c}\text { Model 5 } \\
\text { R\&D }\end{array}$ & $\begin{array}{c}\text { Model 6 } \\
\text { Leverage }\end{array}$ \\
\hline Lagged & $0.194^{* * *}$ & $0.582^{* * *}$ & $0.317^{* * *}$ & $0.645^{* * *}$ \\
& $(0.000)$ & $(0.000)$ & $(0.000)$ & $(0.000)$ \\
CEO with foreign working experience & $-0.016^{* * *}$ & $-0.038^{*}$ & & \\
& $(0.000)$ & $(0.070)$ & & $0.014^{* * *}$ \\
CEO with foreign education & & & $0.028^{* *}$ \\
& & & $(0.000)$ & $(0.031)$ \\
\hline
\end{tabular}


Table 6. Continued

\begin{tabular}{lcccc}
\hline Variables & $\begin{array}{c}\text { Model } 3 \\
\text { R\&D }\end{array}$ & $\begin{array}{c}\text { Model 4 } \\
\text { Leverage }\end{array}$ & $\begin{array}{c}\text { Model 5 } \\
\text { R\&D }\end{array}$ & $\begin{array}{c}\text { Model 6 } \\
\text { Leverage }\end{array}$ \\
\hline Controls & Yes & Yes & Yes & Yes \\
Industry and year fixed effects & Yes & Yes & Yes & Yes \\
Number of observations & 1013 & 3114 & 1013 & 3114 \\
Number of groups & 159 & 510 & 159 & 510 \\
AR(1) test & $-2.820^{*}$ & $-6.264^{*}$ & $-2.446 *$ & $-7.568^{*}$ \\
& {$[0.005]$} & {$[0.000]$} & {$[0.014]$} & {$[0.000]$} \\
AR(2) test & -0.015 & -0.400 & 0.153 & -0.831 \\
& {$[0.988]$} & {$[0.689]$} & {$[0.878]$} & {$[0.406]$} \\
Hansen test & 43.727 & 42.869 & 53.182 & 62.740 \\
& {$[0.686]$} & {$[0.719]$} & {$[0.544]$} & {$[0.312]$} \\
\hline
\end{tabular}

Notes: Figures in parentheses are p-values; $* * *, * *$ and $*$ denote significance at $1 \%, 5 \%$ and $10 \%$ respectively. For the $A R(1), A R(2)$ and Hansen tests, figures in [ ] are p-values and * denotes significance at $5 \%$.

Table 7. GMM regression results for testing H3

\begin{tabular}{|c|c|c|c|c|}
\hline Variables & $\begin{array}{l}\text { Model } 7 \\
\text { R\&D }\end{array}$ & $\begin{array}{l}\text { Model } 8 \\
\text { Leverage }\end{array}$ & $\begin{array}{l}\text { Model } 9 \\
\text { R\&D }\end{array}$ & $\begin{array}{l}\text { Model } 10 \\
\text { Leverage }\end{array}$ \\
\hline Lagged & $\begin{array}{l}0.373^{* * *} \\
(0.000)\end{array}$ & $\begin{array}{l}0.682^{* * *} \\
(0.000)\end{array}$ & $\begin{array}{l}0.282^{* * *} \\
(0.000)\end{array}$ & $\begin{array}{l}0.649 * * * \\
(0.000)\end{array}$ \\
\hline \multicolumn{5}{|c|}{ Panel B: CEO with foreign working experience } \\
\hline OECD & $\begin{array}{l}-0.001 \\
(0.135)\end{array}$ & $\begin{array}{l}-0.002 \\
(0.866)\end{array}$ & & \\
\hline non-OECD & $\begin{array}{l}-0.004 * * * \\
(0.000)\end{array}$ & $\begin{array}{l}-0.012^{*} \\
(0.051)\end{array}$ & & \\
\hline \multicolumn{5}{|c|}{ Panel C: CEO with foreign education } \\
\hline OECD & & & $\begin{array}{c}0.004^{*} \\
(0.092)\end{array}$ & $\begin{array}{c}0.025 * * \\
(0.033)\end{array}$ \\
\hline non-OECD & & & $\begin{array}{l}-0.004 \\
(0.228)\end{array}$ & $\begin{array}{l}-0.008 \\
(0.578)\end{array}$ \\
\hline Controls & Yes & Yes & Yes & Yes \\
\hline Industry and year fixed effects & Yes & Yes & Yes & Yes \\
\hline Number of observations & 1013 & 3114 & 1013 & 3114 \\
\hline Number of groups & 159 & 510 & 159 & 510 \\
\hline $\mathrm{AR}(1)$ test & $\begin{array}{l}-2.287^{*} \\
{[0.022]}\end{array}$ & $\begin{array}{l}-7.627^{*} \\
{[0.000]}\end{array}$ & $\begin{array}{l}-2.324^{*} \\
{[0.020]}\end{array}$ & $\begin{array}{l}-7.753^{*} \\
{[0.000]}\end{array}$ \\
\hline$A R(2)$ test & $\begin{array}{c}0.366 \\
{[0.714]}\end{array}$ & $\begin{array}{l}-0.71 \\
{[0.478]}\end{array}$ & $\begin{array}{c}0.159 \\
{[0.874]}\end{array}$ & $\begin{array}{l}-0.885 \\
{[0.376]}\end{array}$ \\
\hline Hansen test & $\begin{array}{l}49.704 \\
{[0.944]}\end{array}$ & $\begin{array}{l}96.12 \\
{[0.310]}\end{array}$ & $\begin{array}{l}67.626 \\
{[0.558}\end{array}$ & $\begin{array}{l}89.913 \\
{[0.600]}\end{array}$ \\
\hline
\end{tabular}

Notes: Figures in parentheses are p-values; ${ }^{* * *}, * *$ and $*$ denote significance at $1 \%, 5 \%$ and $10 \%$ respectively. For the $A R(1), A R(2)$ and Hansen tests, figures in [ ] are p-values and * denotes significance at $5 \%$. 
The results of the GMM system of tests reported for all models in Tables 5 to 7 support the consistency of the estimate. The $A R(1)$ and $A R(2)$ tests indicate the existence of serial correlation of order one, but not of order two. The Hansen J-statistic is not significant, confirming that the instruments used in the GMM estimation are valid. Besides, the dynamic nature of R\&D and leverage are confirmed as the estimated coefficient of the previous year's R\&D and leverage (Lagged R\&D and Leverage) is positive and statistically significant.

Our research provides compelling empirical evidence that not only the foreign experience per se, but also the type and location of international experience has a significant effect on risk-taking behaviour of the CEO. Our preliminary examination exhibits a negative relationship between managerial risk-taking and foreign experience of CEOs.

By splitting the CEOs to CEOs with working and education experience in foreign countries, we analyse the foreign experience in greater depth. Our results show that CEOs with foreign working experience undertake lower levels of risk-taking while CEOs with foreign education experience demonstrate higher levels of risk-taking.

This is consistent with the argument that CEOs with extensive levels of international working experience may be less accustomed to the domestic way of doing things (Nielsen \& Nielsen, 2013) and less acclimatised to changes and risk in the home country as they may become unfamiliar with the local business environment after years of living abroad (Yuan \& Wen, 2018). This also supports the detrimental effects of increasing international work experience (Schmid \& Altfeld, 2018). As compared to working experience, Malaysian CEOs who study abroad generally spend a shorter time in foreign countries. They mainly study their tertiary education overseas in the form of twinning programmes with the final one or two years of study in foreign universities. With a wider global view and better knowledge from overseas education and better adaptation to local culture, they have higher tolerance levels and are more able to handle risk in the local business environment. They also have a higher ability to identify local business opportunities and make strategic risky investment and financial decisions.

We further extend our study to examine whether foreign experience from OECD countries matters to the level of risk-taking of the firm. When we split the Malaysian CEOs' OECD experience into working and education aspects, we find that CEOs' working experience in non-OECD countries exhibit lower level of risk-taking and CEOs' education experience in OECD countries posits higher levels of risk-taking. This demonstrates that the transfer of knowledge from OECD countries only takes effect for Malaysian CEOs who have foreign education in developed countries.

\section{Additional Analyses}

As the findings above demonstrate that foreign working experience may have adverse effects on corporate risk-taking, we conduct additional analysis to investigate whether certain characteristics of emerging economies may promote the risk-taking behaviour of CEOs. Prior research generally clusters factors that influence a CEO whether to take a riskier approach when responding to uncertainty into three major determinants, namely characteristics of decision maker, organisational context and characteristics of 
environment (Hoskisson et al., 2017; March \& Shapira, 1987). Although emerging countries have undergone rapid economic development, most of the emerging economies are associated with less developed labour markets, weak legal institutions and weak legal protection which may hinder entrepreneurial and innovative activities (Yuan $\&$ Wen, 2018). Based on this notion, we conduct additional analysis to investigate whether CEO characteristics, institutional characteristics of firms and better corporate governance mechanisms in emerging countries may promote managerial risk-taking, especially among CEOs with foreign working experience.

\subsection{Age of CEO}

First, we analyse whether the age of CEOs has a significant impact on risk-taking propensity. Generally, populations worldwide are facing an aging problem due to lower birth rates and increased life expectancy (Jackson et al., 2011). Emerging markets are also moving towards an aging nation and as compared to developed nations, economic drain is expected as the population workforce grows older before the socioeconomic status improves intensely (Crittenden \& Crittenden, 2012). There are many old-aged CEOs in Malaysia who are still holding executive chairman or managing director positions in the firms into their 70s and 80s. They have started the business since the independence of Malaysia in 1957 and develop their entrepreneurial endeavour from then on.

Prior empirical studies on the relationship between CEO age and risk-taking behaviour have produced mixed results. One stream of literature predicts that older CEOs exhibit more risk-aversion due to aging effects. Older managers are less able to integrate information and utilise information base effectively (Taylor, 1975). Older CEOs also face more difficulty to grasp new ideas and learn new behaviour (Hambrick \& Mason, 1984). Firms managed by older CEOs tend to undertake lower levels of R\&D investment and financial leverage (Li et al., 2017; Serfling, 2014). Another strand of studies contends that older managers are more willing to take risks due to the experience effect. The more the past experience of a manager in dealing with risk, the more reasonable the risk will seem to be. As a result, they are less likely to perceive uncertainty of outcome associated with the risk (Sitkin \& Pablo, 1992). Older CEOs with greater experience in dealing with risk have higher ability to identify risky outcomes that will bring the greatest probability of success (Simsek, 2007).

\subsection{Family CEO}

Second, we examine the role of family ownership in mitigating risk-aversion behaviour of CEOs. Similar to other emerging countries, the ownership of firms in Malaysia is concentrated in family-controlled firms (Thillainathan, 1999). Family firms have higher levels of risk tolerance than non-family firms as risk preference of family CEOs incorporates familial objectives in their decision making (Poletti-Hughes \& Williams, 2017). According to socioemotional wealth concept, family firms, particularly in emerging economies are emotionally connected to the affective endowment of their family entities. Family firms seek to retain control and ownership for the future 
generation to preserve family dynastic perpetuation (Gómez-Mejía et al., 2007). Family firms promote long-term objectives by undertaking risky strategies such as higher involvement in entrepreneurial activities and expansion of business operations (Rogoff \& Heck, 2003).

\subsection{High Board Independence}

Third, we investigate whether better corporate governance mechanisms with higher board independence may promote risky behaviour of CEOs. Agency conflict arises from different attitudes towards risk between managers and shareholders (Jensen \& Meckling, 1976). Shareholders or investors who can diversify risk through ownership portfolios tend to prefer risky projects, while managers who cannot diversify their employment risk are more conservative to reduce the risk of losing their job (Amihud \& Lev, 1981; Hirshleifer \& Thakor, 1992). An independent board, with a majority of outside directors, can serve as an important governance mechanism to mitigate managerial pursuit of private benefits. Previous research shows that a board with more independent directors is effective in aligning risk preference of managers with shareholders and hence promoting managerial risk-taking (Lu \& Wang, 2018). Emerging economies are always associated with weak legal rights and investor protection (Connelly et al., 2012). Nevertheless, the Securities Commission Malaysia has outlined in the Malaysian Code on Corporate Governance (MCGG) on requirements of at least a third of the board is independent and has called upon public listed companies to have at least half of the board comprising of independent directors as an effort of placing a greater emphasis on the best practice of corporate governance in Malaysia.

\subsection{Result of Additional Analysis}

We test whether CEO age, CEOs in family firms (family CEO) and firms with high board independence may moderate the relationship between foreign experience and managerial risk-taking. CEO age (AGE) is a continuous variable indicating CEO age in the given year. Family CEO (FAM) is a dummy variable equal to one if the CEO owns at least $5 \%$ of the shares, or has family relationship with directors or major shareholders of the family firm. We indicate a high independence board ( $\mathrm{HBI}$ ) as a dummy variable equal to one if the ratio of number of independent directors on the board is equal to or more than 0.5 . All regression control variables and including industry and year fixed effects as in baseline regressions in Table 5 .

As shown in Table 8, when we interact the age of CEO (AGE) with foreign working experience, the coefficient estimates of CEO with foreign working experience $\times$ AGE is negative. This indicates that younger CEOs undertake higher levels of R\&D investment and leverage. When we test the interaction term of family CEO (FAM), CEO with foreign working experience $\times$ FAM is positively associated with R\&D and leverage. Similarly, when the interaction term of high board independence $(\mathrm{HBI})$ is added to the regression, CEO with foreign working experience $\times \mathrm{HBI}$ is positively associated with R\&D. As for CEOs with foreign education, high board independence also demonstrates a positive moderating effect for R\&D but the age of CEO and family CEO interaction terms show 
no significant effect. This demonstrates that younger CEOs are able to learn new behaviour and grasp new ideas from their working experience in foreign countries. Besides, commitment of family CEOs to preserve the familial perpetuation of the firm and the presence of better corporate governance with higher board independence may also motivate the risk-taking behaviour of CEOs with foreign working experience.

Table 9 shows the results of interaction effect between family CEO and board independence with foreign working and education experience from OECD vs non-OECD countries. Younger CEOs with working experience in OECD countries display higher levels of R\&D investment. Besides, the findings show that foreign working experience from OECD countries is positively related to R\&D and leverage if the CEO is a family CEO, but there is no significant moderating effect of high board independence. This demonstrates that the transfer of global knowledge and advanced technology from working experience in OECD countries only foster a higher level of risk-taking if the CEO is younger and if he or she is a family CEO. This is because younger CEOs may have higher ability to utilise information and knowledge gained from working in OECD countries and thus enhance their risk-taking propensity. Similarly, knowledge spillover from working experience in developed countries have greater effect on family CEOs due to higher concern on growth of family business and preservation of family legacy.

\section{Conclusions}

We investigate the relationship between the foreign experience of CEOs and the risky corporate policies. The process of globalisation is increasingly driving the importance for these scarce internationally-seasoned CEOs. In this study, we employ a sample of public listed firms in Malaysia over the period of 2009 to 2017 to investigate whether the foreign experience of a CEO impacts his/her risk-taking behaviour in investment and financial policies of a firm.

By decomposing the CEOs' foreign experience, our findings demonstrate that foreign education plays a major role in stimulating risk-taking behaviour of CEOs. We document that CEOs with foreign education experience exhibit higher levels of risktaking and CEOs with foreign working experience demonstrate lower levels of risktaking. Furthermore, we find that education experience in OECD countries promotes risk-taking activities and working experience in non-OECD countries adversely affects the risky investment of the firm. This exhibits that the spillover effect of developed countries to emerging markets only takes place for CEOs with foreign education in OECD countries. The advanced technological knowledge and highly specialised skills gained during education in developed nations have improved their innovation capabilities and enhanced their entrepreneurial abilities. Further analysis of study reveals that age of CEO, family firms and better corporate governance mechanism matter in reinforcing risky behaviour of CEOs. The findings show that risk-taking behaviour of CEOs with foreign working experience are being fostered if the CEO is younger and is a family member of the firm.

This study has enhanced our understanding of the effect of foreign experience of a CEO on managerial risk-taking of the firm. First, our study contributes to the literature that uses upper echelons theory in exploring how risk-taking behaviour of the firm can 


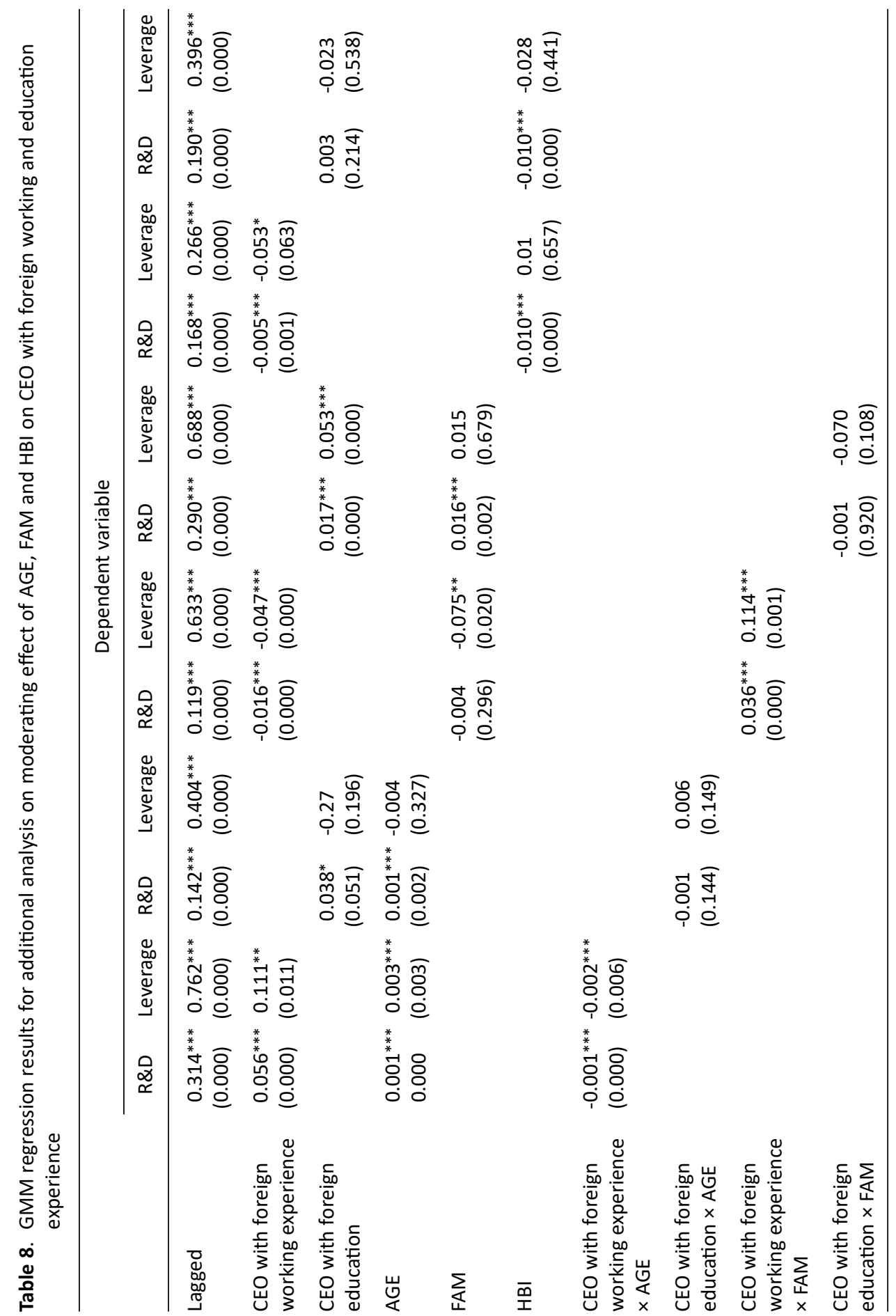




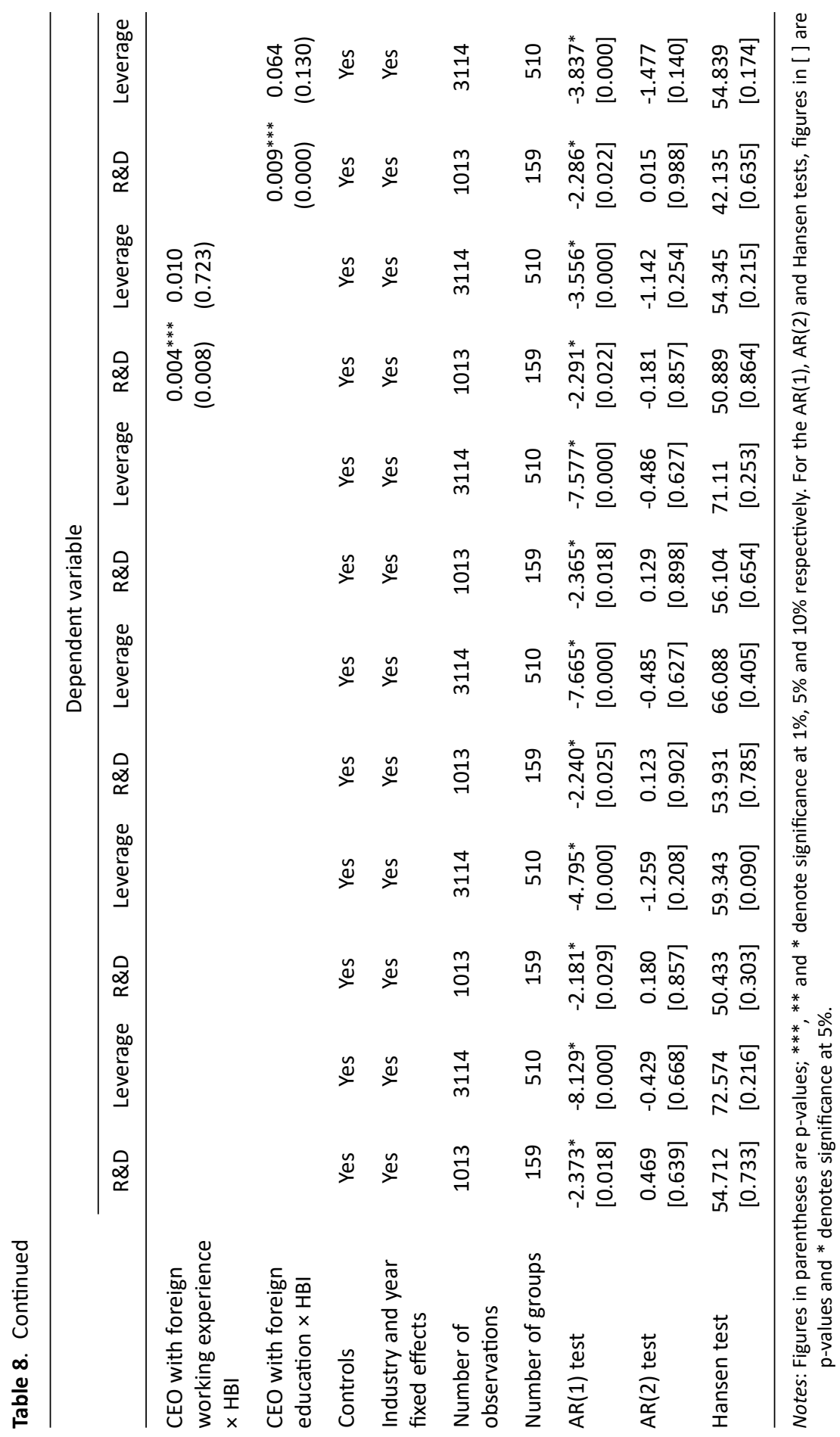




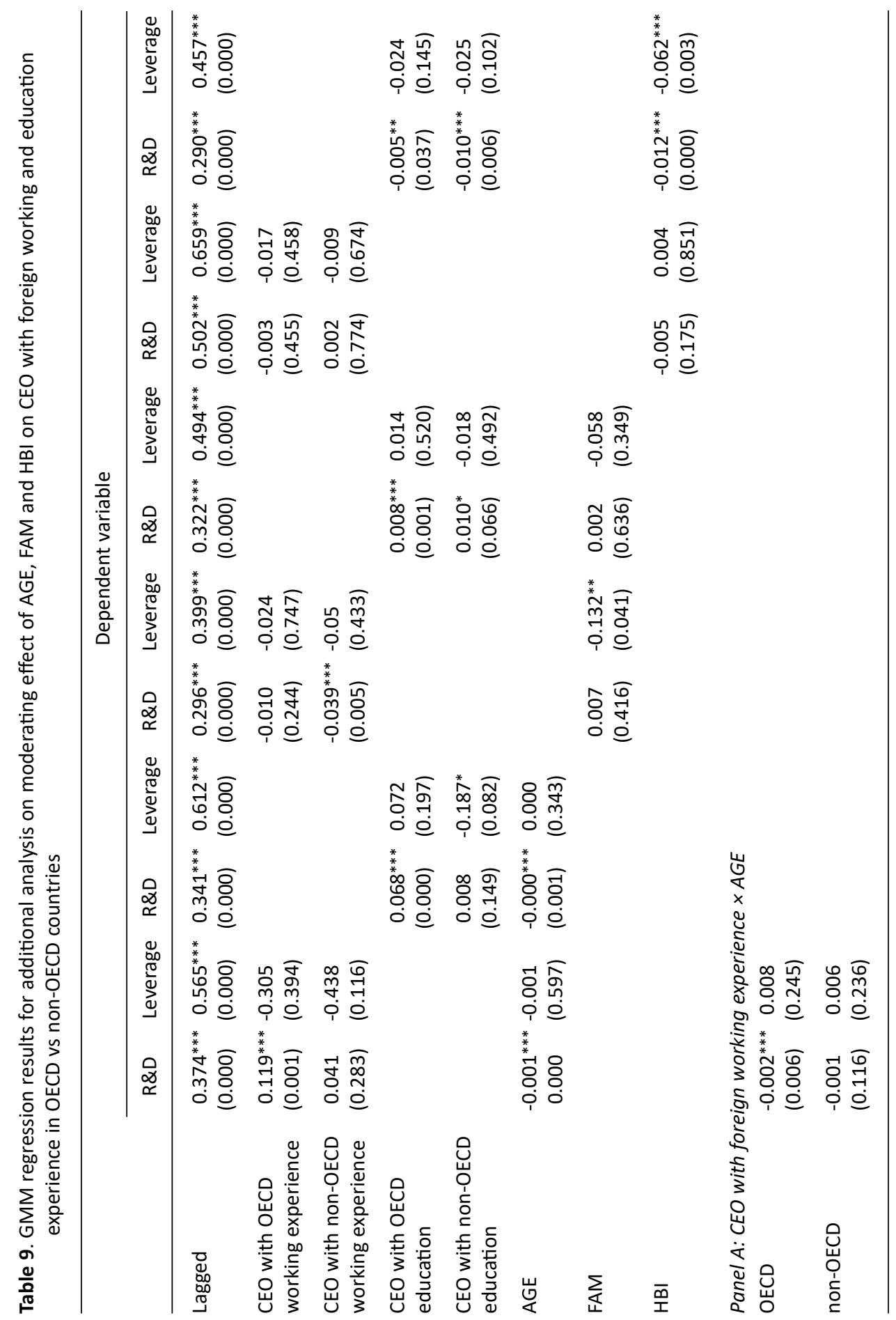


Foreign Experience of CEOs and Managerial Risk Taking

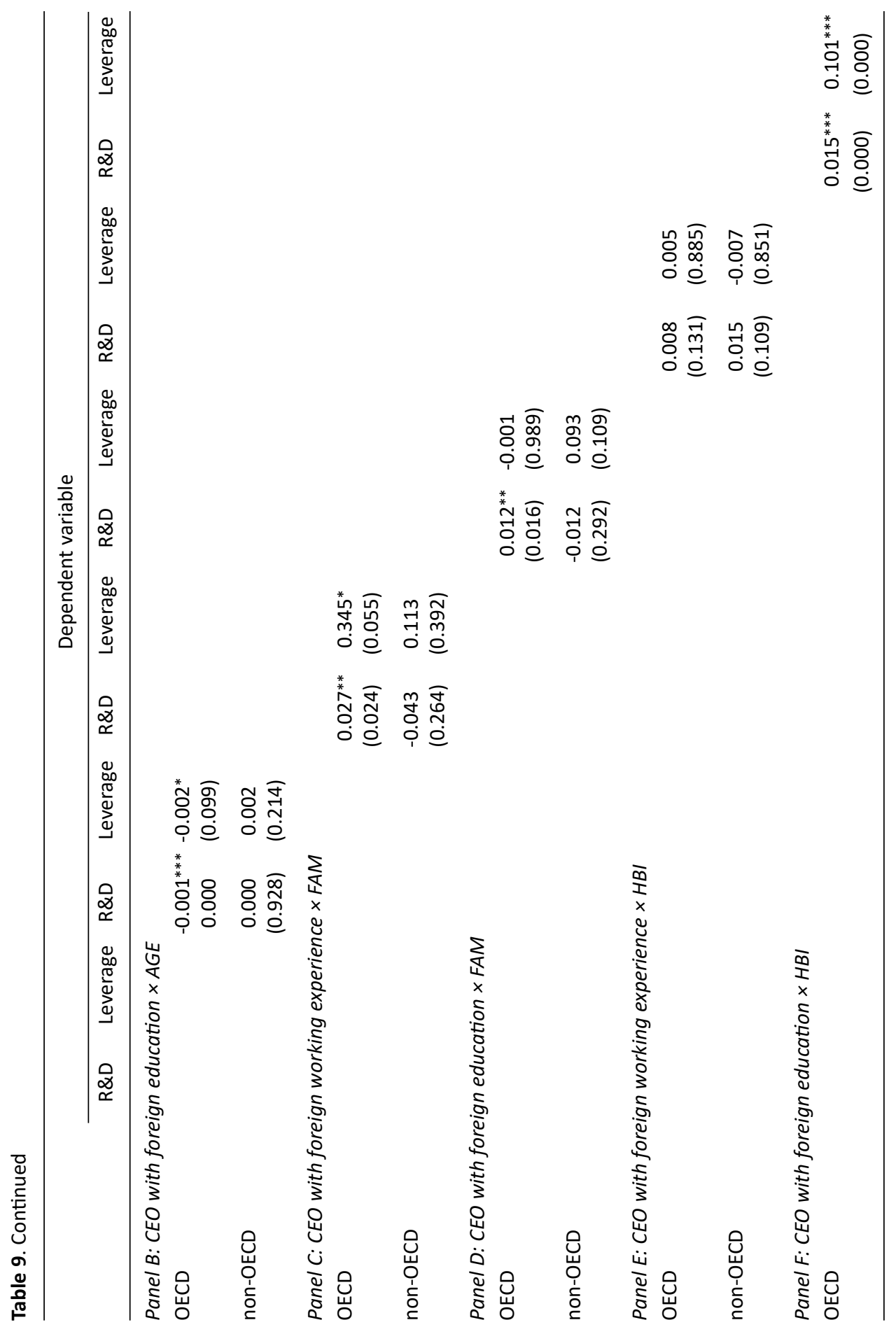


Siew-Boey, Yeoh and Chee-Wooi, Hooy

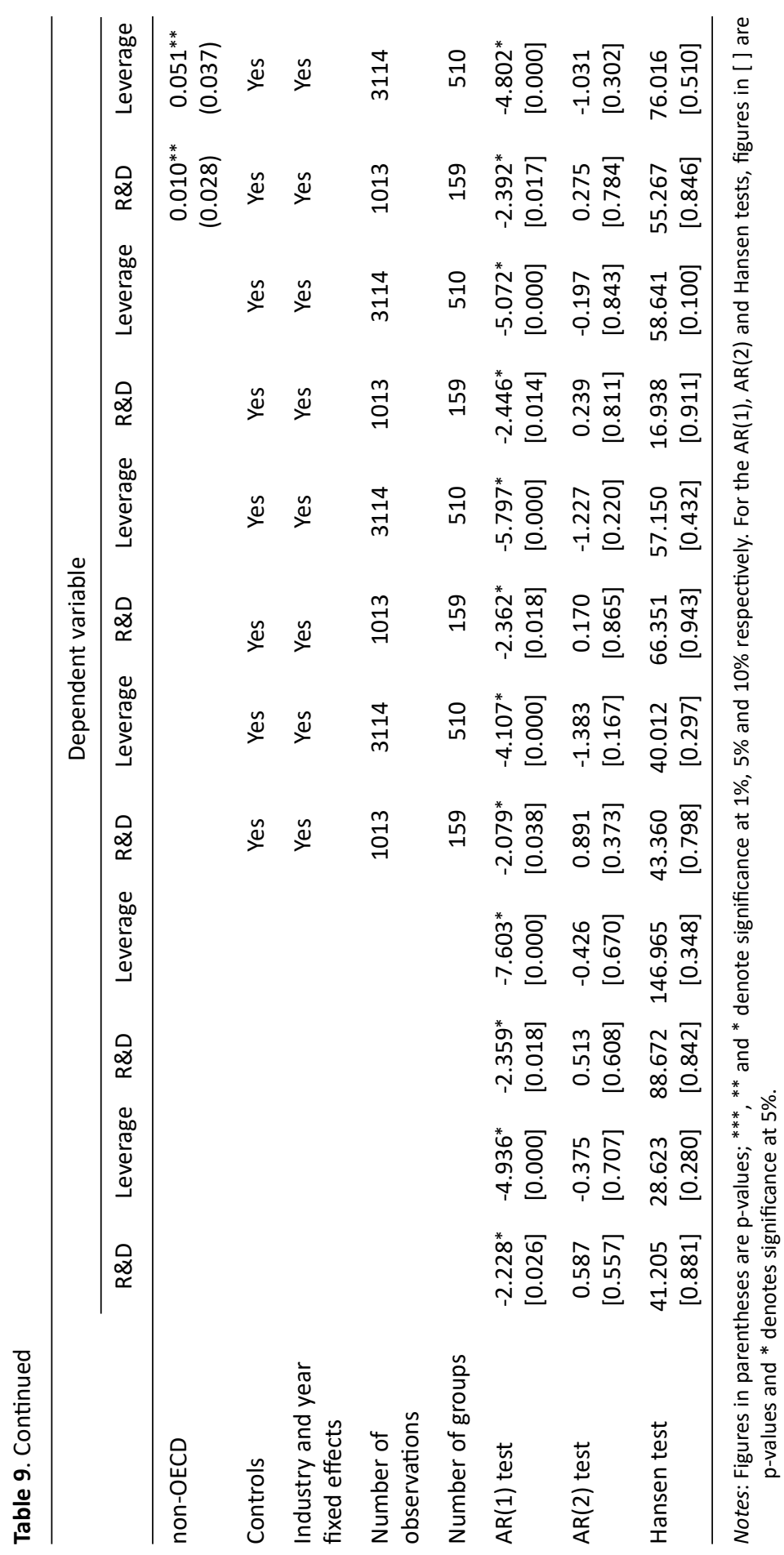


be predicted by personal attributes of a CEO. Prior literature on managerial risk-taking has focused on how characteristics of CEOs affect the riskiness of corporate policy (Barker III \& Mueller, 2002; Elsaid \& Ursel, 2011; Hambrick \& Mason, 1984). Our study helps to explain the effect of observable characteristics as a determinant of CEO's risktaking behaviour.

Second, the empirical results of this study contribute to the growing body of research examining the implication of CEO foreign experience to risky corporate policies (Yuan \& Wen, 2018). Debate persists about the effect of CEO foreign experience on corporate risk-taking of a firm. Our study enriches this line of research by decomposing the effect of foreign experience of CEOs in two distinct aspects, namely CEOs with foreign working and education experience. This provides a more comprehensive measure to fully capture CEOs' international exposure.

Third, our study also has important practical implications. Emerging countries should foster risk-taking behaviour of firms as the competitive business environment is full of uncertainty. As R\&D is crucial in enhancing the competitive advantage of a firm and financial leverage is a source of funding for investment growth, risk-taking propensity of CEOs play a major role in improving the economic development of a firm. Our findings show that foreign experience of CEOs enhances the innovation productivity and financial leverage of the firm. This is specifically important to the emerging markets with scarce talents in innovation. Thus, this study may provide some incentives for firms and policy makers to attract and recruit talents with superior advanced knowledge and highly specialised skills gained from foreign education in developed countries.

\section{References}

Abdel-Khalik, A.R. (2014). CEO risk preference and investing in R\&D. Abacus, 50(3), 245-278. https://doi.org/10.1111/abac.12029

Amihud, Y., \& Lev, B. (1981). Risk reduction as a managerial motive for conglomerate mergers. Bell Journal of Economics, 12(2), 605-617. https://doi.org/10.2307/3003575

Arellano, M., \& Bover, O. (1995). Another look at the instrumental variable estimation of errorcomponents models. Journal of Econometrics, 68(1), 29-51. https://doi.org/10.1016/03044076(94)01642-D

Baltagi, B.H., Blien, U., \& Wolf, K. (2012). A dynamic spatial panel data approach to the German wage curve. Economic Modelling, 29(1), 12-21. https://doi.org/10.1016/j.econmod. 2010.08.019

Barker III, V.L., \& Mueller, G.C. (2002). CEO characteristics and firm R\&D spending. Management Science, 48(6), 782-801. https://doi.org/10.1287/mnsc.48.6.782.187

Barney, J. (1991). Firm resources and sustained competitive advantage. Journal of Management, 17(1), 99-120. https://doi.org/10.1177/014920639101700108

Bertrand, M., \& Schoar, A. (2003). Managing with style: The effect of managers on firm policies. Quarterly Journal of Economics, 118(4), 1169-1208. https://doi.org/10.1162/ 003355303322552775

Blundell, R., \& Bond, S. (1998). Initial conditions and moment restrictions in dynamic panel data models. Journal of Econometrics, 87(1), 115-143. https://doi.org/10.1016/S0304-4076(98) 00009-8

Bromiley, P. (1991). Testing a causal model of corporate risk taking and performance. Academy of Management Journal, 34(1), 37-59. https://doi.org/10.2307/256301 
Carney, M., \& Gedajlovic, E. (2003). Strategic innovation and the administrative heritage of East Asian family business groups. Asia Pacific Journal of Management, 20(1), 5-26. https://doi. org/10.1023/A:1022062428231

Carpenter, M.A., Sanders, W.G., \& Gregersen, H.B. (2001). Bundling human capital with organizational context: The impact of international assignment experience on multinational firm performance and CEO pay. Academy of Management Journal, 44(3), 493-511. https://doi. org/10.5465/3069366

Coles, J.L., Daniel, N.D., \& Naveen, L. (2006). Managerial incentives and risk-taking. Journal of Financial Economics, 79(2), 431-468. https://doi.org/10.1016/j.jfineco.2004.09.004

Connelly, J.T., Limpaphayom, P., \& Nagarajan, N.J. (2012). Form versus substance: The effect of ownership structure and corporate governance on firm value in Thailand. Journal of Banking \& Finance, 36(6), 1722-1743. https://doi.org/10.1016/j.jbankfin.2012.01.017

Crittenden, V.L., \& Crittenden, W.F. (2012). Corporate governance in emerging economies: Understanding the game. Business Horizons, 55(6), 567-574. https://doi.org/10.1016/j. bushor.2012.07.002

Dai, O., \& Liu, X. (2009). Returnee entrepreneurs and firm performance in Chinese high-technology industries. International Business Review, 18(4), 373-386. https://doi.org/10.1016/ j.ibusrev.2009.03.004

Daily, C.M., Certo, S.T., \& Dalton, D.R. (2000). International experience in the executive suite: The path to prosperity? Strategic Management Journal, 21(4), 515-523. https://doi. org/10.1002/(SICI)1097-0266(200004)21:4<515::AID-SMJ92>3.0.CO;2-1

Elnahas, A.M., \& Kim, D. (2017). CEO political ideology and mergers and acquisitions decisions. Journal of Corporate Finance, 45, 162-175. https://doi.org/10.1016/j.jcorpfin.2017.04.013

Elsaid, E., \& Ursel, N.D. (2011). CEO succession, gender and risk taking. Gender in Management, 26(7), 499-512. https://doi.org/10.1108/17542411111175478

Faccio, M., Marchica, M.-T., \& Mura, R. (2011). Large shareholder diversification and corporate risk-taking. Review of Financial Studies, 24(11), 3601-3641. https://doi.org/10.1093/rfs/ hhr065

Filatotchev, I., Liu, X., Lu, J., \& Wright, M. (2011). Knowledge spillovers through human mobility across national borders: Evidence from Zhongguancun Science Park in China. Research Policy, 40(3), 453-462. https://doi.org/10.1016/j.respol.2011.01.003

Georgakakis, D., Dauth, T., \& Ruigrok, W. (2016). Too much of a good thing: Does international experience variety accelerate or delay executives' career advancement? Journal of World Business, 51(3), 425-437. https://doi.org/10.1016/j.jwb.2015.11.008

Giannetti, M., Liao, G., \& Yu, X. (2015). The brain gain of corporate boards: Evidence from China. Journal of Finance, 70(4), 1629-1682. https://doi.org/10.1111/jofi.12198

Gómez-Mejía, L.R., Haynes, K.T., Núñez-Nickel, M., Jacobson, K.J.L., \& Moyano-Fuentes, J. (2007). Socioemotional wealth and business risks in family-controlled firms: Evidence from Spanish olive oil mills. Administrative Science Quarterly, 52(1), 106-137. https://doi.org/ 10.2189/asqu.52.1.106

Habib, A., \& Hasan, M.M. (2017). Firm life cycle, corporate risk-taking and investor sentiment. Accounting \& Finance, 57(2), 465-497. https://doi.org/10.1111/acfi.12141

Hall, T.W. (2012). The collateral channel: Evidence on leverage and asset tangibility. Journal of Corporate Finance, 18(3), 570-583. https://doi.org/10.1016/j.jcorpfin.2011.12.003

Hambrick, D.C. (2007). Upper echelons theory: An update. Academy of Management Review, 32(2), 334-343. https://doi.org/10.5465/amr.2007.24345254

Hambrick, D.C., \& Mason, P.A. (1984). Upper echelons: The organization as a reflection of its top managers. Academy of Management Review, 9(2), 193-206. https://doi.org/10.5465/ amr.1984.4277628 
Herrmann, P., \& Datta, D.K. (2005). Relationships between top management team characteristics and international diversification: An empirical investigation. British Journal of Management, 16(1), 69-78. https://doi.org/10.1111/j.1467-8551.2005.00429.x

Herrmann, P., \& Datta, D.K. (2006). CEO experiences: Effects on the choice of FDI entry mode. Journal of Management Studies, 43(4), 755-778. https://doi.org/10.1111/j.1467-6486. 2006.00610.x

Hirshleifer, D., \& Thakor, A.V. (1992). Managerial conservatism, project choice, and debt. Review of Financial Studies, 5(3), 437-470. https://doi.org/10.1093/rfs/5.3.437

Holmström, B. (1989). Agency costs and innovation. Journal of Economic Behavior and Organization, 12(3), 305-327. https://doi.org/10.1016/0167-2681(89)90025-5

Hoskisson, R.E., Chirico, F., Zyung, J., \& Gambeta, E. (2017). Managerial risk taking: A multitheoretical review and future research agenda. Journal of Management, 43(1), 137-169. https://doi.org/10.1177/0149206316671583

Jackson, R., Howe, N., \& Nakashima, K. (2011). Global aging and the future of emerging markets. Center for Strategic and International Studies.

Jensen, M.C., \& Meckling, W.H. (1976). Theory of the firm: Managerial behavior, agency costs and ownership structure. Journal of Financial Economics, 3(4), 305-360. https://doi.org/ 10.1016/0304-405X(76)90026-X

Kini, O., \& Williams, R. (2012). Tournament incentives, firm risk, and corporate policies. Journal of Financial Economics, 103(2), 350-376. https://doi.org/10.1016/j.jfineco.2011.09.005

Kish-Gephart, J.J., \& Campbell, J.T. (2015). You don't forget your roots: The influence of CEO social class background on strategic risk taking. Academy of Management Journal, 58(6), 1614-1636. https://doi.org/10.5465/amj.2013.1204

Kraimer, M.L., Shaffer, M.A., \& Bolino, M.C. (2009). The influence of expatriate and repatriate experiences on career advancement and repatriate retention. Human Resource Management, 48(1), 27-47. https://doi.org/10.1002/hrm.20265

Kuratko, D.F., Ireland, R.D., Covin, J.G., \& Hornsby, J.S. (2005). A model of middle-level managers' entrepreneurial behavior. Entrepreneurship Theory and Practice, 29(6), 699716. https://doi.org/10.1111/j.1540-6520.2005.00104.x

Lang, L., Ofek, E., \& Stulz, R. (1996). Leverage, investment, and firm growth. Journal of Financial Economics, 40(1), 3-29. https://doi.org/10.1016/0304-405X(95)00842-3

Li, X., Low, A., \& Makhija, A.K. (2017). Career concerns and the busy life of the young CEO. Journal of Corporate Finance, 47, 88-109. https://doi.org/10.1016/j.jcorpfin.2017.09.006

Lu, J., \& Wang, W. (2018). Managerial conservatism, board independence and corporate innovation. Journal of Corporate Finance, 48, 1-16. https://doi.org/10.1016/j.jcorpfin. 2017.10.016

Lumpkin, G.T., \& Dess, G.G. (1996). Clarifying the entrepreneurial orientation construct and linking it to performance. Academy of Management Review, 21(1), 135-172. https://doi. org/10.5465/amr.1996.9602161568

MacCrimmon, K.R., \& Wehrung, D.A. (1990). Characteristics of risk taking executives. Management Science, 36(4), 422-435. https://doi.org/10.1287/mnsc.36.4.422

Mahadevan, R. (2002). A DEA approach to understanding the productivity growth of Malaysia's manufacturing industries. Asia Pacific Journal of Management, 19(4), 587-600. https://doi. org/10.1023/A:1020577811369

March, J.G., \& Shapira, Z. (1987). Managerial perspectives on risk and risk taking. Management Science, 33(11), 1404-1418. https://doi.org/10.1287/mnsc.33.11.1404

Nielsen, B.B., \& Nielsen, S. (2013). Top management team nationality diversity and firm performance: A multilevel study. Strategic Management Journal, 34(3), 373-382. https://doi. org/10.1002/smj.2021 
Nielsen, S. (2010). Top management team internationalization and firm performance: The Mediating Role of Foreign Market Entry. Management International Review, 50(2), 185-206.

Norden, L., \& van Kampen, S. (2013). Corporate leverage and the collateral channel. Journal of Banking \& Finance, 37(12), 5062-5072. https://doi.org/10.1016/j.jbankfin.2013.09.001

Peng, M.W. (2001). How entrepreneurs create wealth in transition economies. Academy of Management Perspectives, 15(1), 95-108. https://doi.org/10.5465/ame.2001.4251397

Poletti-Hughes, J., \& Williams, J. (2017). The effect of family control on value and risk-taking in Mexico: A socioemotional wealth approach. International Review of Financial Analysis, 63, 369-381. https://doi.org/10.1016/j.irfa.2017.02.005

Reed, R., \& DeFillippi, R.J. (1990). Causal ambiguity, barriers to imitation, and sustainable competitive advantage. Academy of Management Review, 15(1), 88-102. https://doi.org/ 10.5465/amr.1990.4308277

Rogoff, E.G., \& Heck, R.K.Z. (2003). Evolving research in entrepreneurship and family business: Recognizing family as the oxygen that feeds the fire of entrepreneurship. Journal of Business Venturing, 18(5), 559-566. https://doi.org/10.1016/S0883-9026(03)00009-0

Sambharya, R.B. (1996). Foreign experience of top management teams and international diversification strategies of US multinational corporations. Strategic Management Journal, 17(9), 739-746. https://doi.org/10.1002/(SICI)1097-0266(199611)17:9<739::AID-SMJ846>3.0.CO;2-K

Saxenian, A. (2006). The new argonauts: Regional advantage in a global economy. Harvard University Press.

Schmid, S., \& Altfeld, F. (2018). International work experience and compensation: Is more always better for CFOs? European Management Journal, 36(4), 530-543. https://doi. org/10.1016/j.emj.2017.11.001

Serfling, M.A. (2014). CEO age and the riskiness of corporate policies. Journal of Corporate Finance, 25, 251-273. https://doi.org/10.1016/j.jcorpfin.2013.12.013

Simon, H.A., \& March, J.G. (1958). Organizations. John Wiley \& Sons Inc.

Simsek, Z. (2007). CEO tenure and organizational performance: An intervening model. Strategic Management Journal, 28(6), 653-662. https://doi.org/10.1002/smj.599

Sitkin, S.B., \& Pablo, A.L. (1992). Reconceptualizing the determinants of risk behavior. Academy of Management Review, 17(1), 9-38. https://doi.org/10.5465/amr.1992.4279564

Sullivan, D. (1994). Measuring the degree of internationalization of a firm. Journal of International Business Studies, 25(2), 325-342.

Taylor, R. N. (1975). Age and experience as determinants of managerial information processing and decision making performance. Academy of Management Journal, 18(1), 74-81. https://doi.org/10.5465/255626

Tong, K.O., \& Ho, K.T. (2019, August 30). Time to exorcise the ghosts of $97 / 98$ and unleash the animal spirits of the private sector. The Edge Markets. https://www.theedgemarkets.com/ article/cover-story-time-exorcise-ghosts-9798

Thillainathan, R. (1999). Corporate governance and restructuring in Malaysia-A review of markets, mechanisms, agents and the legal infrastructure. World Bank/OECD. https://www. oecd.org/corporate/ca/corporategovernanceprinciples/1931380.pdf

Trajtenberg, M. (1990). Economic analysis of product innovation: The case of CT scanners. Harvard University Press.

von den Driesch, T., Da Costa, M.E.S., Flatten, T.C., \& Brettel, M. (2015). How CEO experience, personality, and network affect firms' dynamic capabilities. European Management Journal, 33(4), 245-256. https://doi.org/10.1016/j.emj.2015.01.003

World Bank. (2015). Improving the effectiveness of TalentCorp's Initiatives: Assessment of returning expert programme and residence pass-talent. https://doi.org/10.1596/24453 
Yuan, R., \& Wen, W. (2018). Managerial foreign experience and corporate innovation. Journal of Corporate Finance, 48, 752-770. https://doi.org/10.1016/j.jcorpfin.2017.12.015

Yusoff, M.B., Hasan, F.A., \& Jalil, S.A. (2000). Globalisation, economic policy and equity: The case of Malaysia. Organisation for Economic Co-operation and Development (OECD). https:// www.oecd.org/countries/malaysia/2682426.pdf 
